\title{
Hubungan Kecerdasan Emosional dengan Penerimaan Teman Sebaya serta Implikasinya dalam Bimbingan dan Konseling
}

\author{
Faulla Desri Melka ${ }^{1}$, Riska Ahmad ${ }^{2}$, Firman $^{3}$, Yarmis Syukur $^{4}$, Indah Sukmawati ${ }^{5}, \&$ Puji Gusri \\ Handayani $^{6}$ \\ ${ }^{123}$ Universitas Negeri Padang \\ *Corresponding author, e-mail:faulladesrimelka@gmail.com
}

\begin{abstract}
Abstrack
This research is background by students who experience rejection from peers and become isolated students. One of the factors thought to influence it is emotional intelligence. This purpose of this research is to: Describe the emotional intelligence of students, Describe peer acceptance, and Test the significance of the relationship emotional intelligance with peer acceptance. The research approach uses a quantitative approach with descriptive correlational types. The population of this study was 354 students of SMPN 4 Padang and a sample of 201 students selected with Stratified Random Sampling. Data analyzed with descriptive statistical techniques and Pearson Product Moment techniques with the support of the program SPSS for windows 20. The research findings show that: Students emotional intelligence is in the hight category with a percentage of 60,70\%, Peer acceptance is in a good category with a percentage of $54,73 \%$, and there is a significant positive relationship between emotional intelligence and peer acceptance with a correlation coefficient of 0,504 and a significance level 0,000 .
\end{abstract}

Keyword: Emotional Intelligence, Peer Acceptance.

How to Cite: Faulla Desri Melka, Riska Ahmad, Firman, Yarmis Syukur, Indah Sukmawati, Puji Gusri Handayani 2018. Hubungan Kecerdasan Emosional dengan Penerimaan Teman Sebaya serta Implikasinnya dalam Bimbingan dan Konseling. Konselor, VV (N): pp. XX-XX, DOI: 10.24036/XXXXXXXXXX-X-XX

This is an open access article distributed under the Creative Commons 4.0 Attribution License, which permits unrestricted use, distribution, and reproduction in any medium, provided the original work is properly cited. (O2017 by author and Universitas Negeri Padang.

\section{Pendahuluan}

Masa remaja merupakan salah satu periode perkembangan pada kehidupan manusia. Santrock J. W (2003) menjelaskan remaja sebagai masa transisi antara masa anak-anak dan masa dewasa yang terjadi perubahan biologis, kognitif dan sosial-emosional. Usia remaja dimulai pada usia 10-13 tahun dan berakhir pada usia 18-22 tahun. Usia yang tergolong masih remaja rata-rata berada pada jenjang pendidikan SMP dan SMA.

Sekolah sebagai lingkungan sosial bagi remaja untuk dapat berinteraksi dengan teman sebaya atau orang dewasa lainnya. Jeanne Ellis Ormrod (dalam Rahmawati U.M., 2013) menjelaskan bahwa sekolah sebagai suatu lingkungan sosial, dimana para siswa menjalin hubungan sosial yang menyenangkan dengan teman-temannya, baik itu teman sekelas maupun teman beda kelas. Pertemanan pada remaja di sekolah, tidak hanya terjadi antar siswa dengan kelas yang sama, tetapi pertemanan tersebut juga memungkinkan dijalin oleh siswa dengan tingkat jejang kelas atau sekolah yang berbeda.

Pada masa remaja, remaja akan dihadapkan dengan berbagai tugas perkembangan yang harus dipelajari dan diselesaikan guna mencapai keberhasilan perkembangan pada masa berikutnya. Havighurst (dalam Prayitno, E., 2006) menjelaskan salah satu tugas perkembangan remaja adalah melaksanakan peranan sosial yaitu mampu menyesuaikan diri dan mampu membina hubungan yang baik dengan teman 
sebaya, baik yang sama atau berbeda jenis kelamin. Selain itu, Hurlock E. B (1980) juga menjelaskan salah satu tugas perkembangan remaja adalah mampu bersosialisasi dengan menjalin hubungan antar pribadi dan berinteraksi dengan teman sebaya. Pada masa ini, remaja lebih banyak melibatkan diri dengan kelompok teman sebayanya dari pada orangtua, remaja juga lebih banyak melakukan kegiatan di luar dengan teman-temannya (Octaviyana, Firman, \& Daharnis, 2017). Condry, Simon, \& Bronffenbrenner (dalam Astarini, D, Nirwana, H \& Ahamad, R, 2016) juga menemukan selama satu minggu, remaja menghabiskan waktu dua kali lebih banyak dengan teman sebaya daripada dengan orangtuanya.

Teman sebaya (peers) adalah anak-anak atau remaja yang memiliki usia atau tingkat kematangan yang sama (Santrock J.W, 2007). Remaja menginginkan teman yang mempunyai minat dan nilai-nilai yang sama dengan dirinya, ini artinya remaja menginginkan dirinya diterima oleh teman sebayanya (peer group). Penerimaan teman sebaya berarti dipilihnya remaja sebagai teman untuk suatu aktivitas dalam kelompok. Penerimaan teman sebaya merupakan persepsi tentang diterima atau dipilihnya individu menjadi anggota dalam suatu kelompok tertentu (Hurlock E.B, 1980). Selanjutnya, Rosida, E.R \& Astuti, T.P (2015) juga menjelaskan bahwa penerimaan teman sebaya adalah penilaian individu bahwa dirinya diterima, didengar, diperhatikan, dihargai, serta dapat merasa aman dan nyaman saat bersama dengan teman-temannya. Jadi, penerimaan teman sebaya merupakan penilaian tentang diterima atau dipilihnya individu menjadi anggota dalam suatu kelompok tertentu.

Pada usia remaja, penolakan atau penerimaan dalam pertemanan berpengaruh besar terhadap perkembangan kehidupan sosial remaja itu sendiri. Sebagaimana Prayitno, E (2006) mengatakan bahwa remaja butuh kebanggaan untuk dikenal dan diterima sebagai individu yang berarti dari teman sebayanya. Penerimaan dan dibanggakan oleh teman sebaya sangat penting bagi remaja dalam mencari kepercayaan diri, kemandirian, serta sebagai persiapan awal dalam menempuh kehidupan pada periode remaja. Pada masa ini, remaja memiliki kebutuhan yang kuat untuk disukai dan diterima oleh teman sebaya atau kelompok. Sebagai akibatnya, remaja merasa senang apabila diterima dan sebaliknya akan merasa tertekan dan cemas apabila diremehkan teman sebayanya (Santrock J. W, 2007).

Salah satu faktor yang mempengaruhi penerimaan atau penolakan dari teman sebaya adalah kecerdasan emosional. Goleman (1996) menyebutkan terdapat dua kecenderungan emosional yang menyebabkan anak akhirnya menjadi orang yang ditolak dari pergaulan, yang pertama adalah ketidakmampuan mengendalikan amarah, dan yang kedua adalah sikap takut-takut, cemas, dan malumalu dalam pergaulan. Menurut Goleman (1999) kecerdasan emosi atau emotional intelligence merujuk kepada kemampuan mengenali perasaan sendiri dan perasaan orang lain, kemampuan memotivasi diri sendiri, dan kemampuan mengelola emosi dengan baik pada diri sendiri dan dalam hubungan dengan orang lain.

Prayitno, E (2006) menjelaskan bahwa penolakan dari teman sebaya dapat disebabkan oleh beberapa faktor diantaranya karena ketidaksukaan teman sebaya terhadap sikap remaja, tidak sportif, penampilan fisik tidak sesuai dengan standar kelompok, tidak mampu bekerja sama, sikap egois, perbedaan status, jarak tempat tinggal, serta disebabkan oleh emosi remaja itu sendiri. Santrock J. W (2007) juga menjelaskan bahwa yang memainkan peran penting dalam hubungan sebaya bukan hanya kognisi melainkan juga emosi. Jika siswa tidak mampu mengendalikan emosinya akan bisa merusak hubungan teman sebayanya. Remaja yang memiliki emosi negatif lebih sering mengalami penolakan oleh teman sebayanya, sementara remaja yang memiliki emosi positif akan lebih diterima dan popular dalam pertemanannya (Saarni dalam Santrock J. W., 2007).

Jenis emosi yang secara normal sering dialami remaja adalah kasih sayang, gembira, amarah, takut, cemas, cinta, cemburu, kecewa, sedih, dan lain-lain. Rasa marah dan permusuhan merupakan gejala emosional yang penting diantara emosi-emosi yang menonjol dalam perkembangan kepribadian remaja. Oleh karena itu remaja harus menjaga, mengatur, serta mengendalikan emosi yang dialaminya agar terhindar dari penolakan teman sebaya (Fatimah, E, 2006).

Berdasarkan hasil penelitian yang dilakukan Purnama N.R (2010) siswa mengalami masalah pada masa pubertas berkaitan dengan aspek fisik dan aspek psikologis. Dalam aspek psikologis, siswa mengalami masalah dalam hal emosi dan sosial yang berada pada kategori sedang. Hasil penelitian Astuti, D (2009) menunjukkan bahwa kecerdasan emosional remaja berada pada kategori rendah. Selanjutnya, temuan penelitian yang dilakukan oleh Yanuarwati, A (2010) menunjukkan penerimaan teman sebaya berada pada kategori tinggi. Herawaty, Y (2015) menunjukkan bahwa penerimaan teman sebaya berada pada kategori sedang. 
Berdasarkan hasil pengolahan sosiometri yang di administrasikan pada tanggal 3 Agustus 2017 di kelas VII di SMPN 4 Padang, terdapat satu orang siswa yang menjadi bintang kelas, dua klik, delapan terisolir, dan dua orang memutuskan untuk tidak menentukan pilihannya. Kemudian di kelas lainnya juga terdapat satu orang bintang kelas, tujuh klik, dan terdapat sebelas siswa terisolir. Melalui penjelasan di atas dapat diketahui bahwa masih banyak siswa yang berada pada kategori terisolir di kelasnya sendiri. Berdasarkan hasil wawancara peneliti dengan salah satu guru Bimbingan dan Konseling (guru BK) menjelaskan bahwa ada siswa yang sering mengganggu temannya yang sedang belajar dan membuat keributan di dalam kelas, seperti: bersikap kasar, berbicara keras serta sering bertengkar, sehingga siswa tersebut sering di abaikan di dalam kelas oleh teman-temannya. Selanjutnya hasil wawancara dengan empat orang siswa pada tanggal 15 November 2017 adalah ada siswa yang kurang mampu untuk mengendalikan emosinya, seperti: mudah marah, suka menyindir-nyindir, dan mengganggu temannya, sehingga banyak teman yang tidak mau berteman dengannya.

Guru BK memiliki peran yang cukup besar dalam upaya penyelesaian masalah siswa, karena salah satu tugas guru BK adalah membantu menyelesaikan KES-T (Kehidupan Efektif Sehari-hari Terganggu) yang dialami oleh siswa. Namun, sangat disayangkan siswa yang dalam masa perkembangan remaja seharusnya diterima oleh teman sebayanya mengalami penolakan yang diakibatkan oleh emosi yang ditampilkannya seperti yang dilihat pada fenomena di lapangan. Setelah diketahui bagaimana kecerdasan emosional dan penerimaan teman sebaya siswa, maka akan terlihat layanan-layanan yang dibutuhkan oleh siswa yang diberikan oleh guru BK. Guru BK dapat memberikan layanan-layanan sesuai dengan kebutuhan dan permasalahan yang dialami oleh siswa. Dengan begitu guru BK dapat berperan dalam membantu siswa menyelesaikan permasalahan-permasalahannya.

\section{Metode Penelitian}

Penelitian ini merupakan penelitian kuantitatif dengan dengan jenis deskriptif korelasional. Populasi yang digunakan sebanyak 354 orang siswa SMPN 4 Padang yang terdaftar pada tahun pelajaran 2017/2018 dan sampel penelitian sebanyak 201 orang siswa yang dipilih dengan Stratified Random Sampling. Instrumen yang digunakan dalam mengumpulan data pada penelitian ini adalah angket kecerdasan emosional dengan reliabilitas 0,873 dan angket penerimaan teman sebaya dengan reliabilitas 0,863. Data yang dikumpulkan dianalisis menggunakan statistik deskriptif dan teknik Pearson Product Moment dengan bantuan program SPSS for windows 20.

\section{Hasil dan Pembahasan}

Hasil penelitian disajikan dan dianalisis sesuai dengan tujuan penelitian yang telah peneliti ajukan sebelumnya yaitu mendeskripsikan penerimaan teman sebaya, mendeskripsikan kecerdasan emosional siswa, dan menguji signifikansi hubungan kecerdasan emosional dengan penerimaan teman sebaya.

\section{Penerimaan Teman Sebaya}

Secara keseluruhan, penerimaan teman sebaya siswa berada pada kategori baik. Sebanyak 17 orang siswa berada pada kategori sangat baik dalam penerimaan teman sebayanya dengan persentase $8,46 \%, 110$ orang siswa $(54,73 \%)$ berada pada kategori baik, 70 orang siswa $(34,83 \%)$ berada pada kategori cukup baik, 4 orang siswa $(1,99 \%)$ berada pada kategori kurang baik, dan tidak ada siswa yang dalam penerimaan teman sebayanya berada pada kategori tidak baik dengan persentase $0 \%$. Temuan ini membuktikan bahwa penerimaan teman sebaya pada siswa di SMPN 4 Padang berada pada kategori baik.

Penerimaan teman sebaya merupakan penilaian tentang diterima atau dipilihnya individu menjadi anggota dalam suatu kelompok tertentu. Menurut Mappiare (dalam Herawaty, Y. 2015) diterimanya remaja oleh teman sebayanya akan membuat salah satu kebutuhan remaja tersebut terpenuhi. Hal ini disebabkan karena penerimaan teman sebaya merupakan salah satu kelompok kebutuhan remaja, disamping kebutuhan yang berhubungan dengan para orangtua. Akibat langsung adanya penerimaan teman sebaya bagi seorang remaja adalah rasa berharga dan berarti serta dibutuhkan bagi atau oleh kelompoknya. Hal ini akan menimbulkan rasa senang, puas pada remaja.

\section{Kecerdasan Emosional}

Secara keseluruhan, kecerdasan emosional siswa berada pada kategori tinggi. sebanyak 48 orang siswa memiliki kecerdasan emosional pada kategori sangat tinggi dengan persentase $23,88 \%$, 122 orang siswa $(60,70 \%)$ berada pada kategori tinggi, 31 orang siswa $(15,42 \%)$ berada pada 
kategori sedang, dan tidak ada siswa yang memiliki kecerdasan emosional pada kategori rendah dan sangat rendah dengan persentase $0 \%$. Temuan ini membuktikan bahwa kecerdasan emosional siswa di SMPN 4 Padang berada pada kategori tinggi.

Kecerdasan Emosional merupakan kemampuan individu untuk mengendalikan emosi dalam menghadapi berbagai situasi untuk mencapai suatu tujuan. individu yang memiliki kecerdasan emosi yang baik, apabila memiliki hubungan sosial yang matang, mudah berteman, jenaka, tidak mudah takut atau gelisah, mampu menyesuaikan diri dengan beban stres, serta memiliki kemampuan besar untuk melibatkan diri dengan orang-orang atau permasalahan, untuk mengambil tanggung jawab, dan memiliki pandangan moral (Sahputra D, Syahniar, \& Marjohan, 2016). Jenis emosi yang secara normal sering dialami remaja adalah kasih sayang, gembira, amarah, takut, cemas, cinta, cemburu, kecewa, sedih, dan lain-lain. Rasa marah dan permusuhan merupakan gejala emosional yang penting diantara emosi-emosi yang menonjol dalam perkembangan kepribadian remaja. Oleh karena itu remaja harus menjaga, mengatur, serta mengendalikan emosi yang dialaminya agar terhindar dari penolakan teman sebaya (Fatimah, E, 2006).

\section{Hubungan Kecerdasan Emosional dengan Penerimaan Teman Sebaya}

Hasil uji hipotesis dimaksudkan untuk mengetahui hubungan kecerdasan emosional dengan penerimaan teman sebaya siswa di SMPN 4 Padang. Adapun hipotesis yang dikemukakan pada penelitian ini yaitu terdapat hubungan positif yang signifikan antara kecerdasan emosional dengan penerimaan teman sebaya.

Hasil penelitian menunjukkan bahwa terdapat hubungan positif yang signifikan antara kecerdasan emosional dengan penerimaan teman sebaya pada siswa di SMPN 4 Padang dengan koefisien korelasi sebesar 0,504 dengan taraf signifikansi 0,000. Hal ini membuktikan bahwa terdapat hubungan positif yang signifikan antara kecerdasan emosional dengan penerimaan teman sebaya. Hubungan yang positif signifikan ini dapat diartikan, semakin tinggi kecerdasan emosional siswa maka semakin baik penerimaan teman sebaya. Sebaliknya, semakin rendah kecerdasan emosional siswa maka semakin tidak baik penerimaan teman sebaya.

Pada usia remaja penerimaan atau penolakan dalam pertemanan berpengaruh besar terhadap perkembangan kehidupan sosial remaja itu sendiri. Pada masa ini, remaja memiliki kebutuhan yang kuat untuk disukai dan diterima teman sebaya atau kelompok. Sebagai akibatnya, mereka merasa senang apabila diterima dan sebaliknya akan merasa tertekan dan cemas apabila diremehkan teman sebayanya (Santrock J. W, 2007). Penolakan dari teman sebaya dapat disebabkan oleh beberapa faktor diantaranya karena ketidaksukaan teman sebaya terhadap sikap remaja, tidak sportif, penampilan fisik tidak sesuai dengan standar kelompok, tidak mampu bekerja sama, sikap egois, perbedaan status, jarak tempat tinggal, serta disebabkan oleh emosi remaja itu sendiri (Prayitno, E, 2006). Goleman (1996) terdapat dua kecenderungan emosional yang menyebabkan anak akhirnya menjadi orang yang ditolak dari pergaulan, yang pertama adalah ketidakmampuan mengendalikan amarah, dan yang kedua adalah sikap takut-takut, cemas, dan malu-malu dalam pergaulan. Albin R.S (1986) juga menyebutkan bahwa emosi dapat mempererat hubungan dan sebaliknya juga dapat memisahkannya. Selain itu Argle, dkk (dalam Paulo N. Lopes \& Peter, 2004) menjelaskan bahwa menampilkan emosi yang menyenangkan cenderung memperoleh respon positif dari orang lain, sedangkan emosi negarif sering mendorong orang lain untuk menjauh. Siswa yang menampilkan emosi dengan teriakan, meledak-ledak cacian dan makian membuat teman sebaya takut dan menjauhi siswa yang bersangkutan.

\section{Implikasi dalam Pelayanan Bimbingan dan Konseling}

Bimbingan dan konseling merupakan salah satu cara yang bisa dilakukan untuk mencari pemecahan ataupun mencegah terjadinya masalah pada diri siswa. Remaja yang berada pada posisi yang sangat rawan dan mudah terjebak dalam situasi yang menyesatkan, membutuhkan petunjuk, bimbingan dan arahan dari orang dewasa untuk membantu mereka mengerti tentang dirinya (Firman \& Nurmina, 2008). Berdasarkan data temuan penelitian yang telah dipaparkan mengenai kecerdasan emosional dan penerimaan teman sebaya, adapun jenis layanan dan materi layanan yang dapat diberikan yaitu sebagai berikut: 
Layanan informasi

Layanan informasi diberikan untuk memenuhi kekurangan informasi yang dibutuhkan siswa. Melalui layanan informasi, guru BK dapat menerapkan fungsi pemahaman pada siswa melalui pembelajaran mengenai materi yang berhubungan dengan kecerdasan emosional. Dengan memperoleh informasi yang tepat dan memadai, siswa akan dapat mempertimbangkan berbagai alternatif pilihan, membuat rencana dan mengambil keputusan untuk kepentingan pribadi dalam merencanakan kehidupan sendiri (Fitri, Y.A, Firman, \& Karneli, Y, 2016). Oleh karena itu, guru BK dapat memberikan materi yang dapat membantu siswa memahami, menggali dan meningkatkan kecerdasan emosional. Adapun materi layanan yang dapat diberikan yaitu pentingya mengenali emosi diri, pentingnya mengenali penyebab timbulnya emosi, pentingnya mengendalikan emosi, manfaat mengelola emosi, pentingnya memotivasi diri, manfaat memotivasi diri, pentingya mengenali emosi orang lain, manfaat megenali emosi orang lain, pentingnya keterampilan berkomunikasi, manfaat bekerja sama. Dengan materi ini, siswa nantinya mampu memahami pentingnya kecerdasan emosional dan manfaat dalam memiliki kecerdasan emosional melalui pemahaman dari sub variabel kecerdasan emosional, sehingga mengetahui bagaimana cara meningkatkan kecerdasan emosionalnya.

Layanan Penguasaan Konten

Layanan penguasaan konten diberikan kepada siswa agar menguasai suatu kemampuan dan kompetensi tertentu. Kaitannya dengan kecerdasan emosional dan penerimaan teman sebaya adalah agar siswa dapat meningkatkan kecerdasan emosionalnya dan diterima dengan baik oleh teman sebayanya, dan tentu saja dengan menggunakan trik-trik atau strategi yang dipelajari. Dengan adanya layanan penguasaan konten ini, diharapkan dapat membantu siswa untuk meningkatkan kecerdasan emosional dan diterima dengan baik oleh teman sebaya.

Adapun materi layanan yang dapat diberikan yaitu sebagai berikut:

Kecerdasan emosional

Materi layanan penguasaan konten yang dapat diberikan yaitu cara mengenali emosi diri, cara mengekspresikan emosi dengan tepat, cara memotivasi diri, cara menjadi pendengar yang baik, dan cara berbicara yang baik dan benar. Dengan materi-materi ini, siswa nantinya mampu menerapkan setiap konten yang dipelajari dan mampu meningkatkan kecerdasan emosionalnya.

Penerimaan teman sebaya

Materi layanan penguasaan konten yang dapat diberikan yaitu cara memberikan pendapat yang baik, strategi menjadi teman yang menyenangkan, cara menjaga hubungan baik dengan teman sebaya, dan trik menjadi pemimpin yang baik. Dengan materi-materi ini, siswa nantinya mampu menerapkan setiap konten yang dipelajari dan diterima dengan baik oleh teman sebayanya.

\section{Layanan Konseling Perorangan}

Prayitno dan Amti, E (2004) menjelaskan bahwa layanan konseling perorangan adalah pelayanan khusus dalam hubungan langsung tatap muka antara konselor dan klien. Melalui layanan konseling perorangan yang diberikan, guru BK dapat melakukan pendekatan untuk mengetahui permasalahan siswa. Melalui layanan ini guru BK dapat menjalankan fungsi pemahaman, pengentasan, dan pencegahan terhadap siswa berkaitan dengan permasalahan yang dimiliki, terutama menyangkut kecerdasan emosional dan penerimaan teman sebaya.

Adapun layanan konseling perorangan ini diberikan sesuai dengan masalah pribadi yang dialami siswa yang ada kaitannya untuk meningkatakan kecerdasan emosional dan penerimaan teman sebaya.

\section{Layanan Bimbingan Kelompok}

Bimbingan kelompok merupakan salah satu jenis layanan dalam bimbingan dan konseling yang memanfaatkan dinamika kelompok dengan tujuan untuk membahas informasi terbaru agar anggota kelompok memperoleh informasi baru dan mampu mengembangkan potensi dirinya, diikuti oleh semua anggota kelompok dan dibawah bimbingan pemimpin kelompok (Tohirin, 2011). Bimbingan kelompok bertujuan menghilangkan ketegangan- 
ketegangan emosi yang dialami siswa (Aswida W, Marjohan, Syukur Y, 2012). Dengan bimbingan kelompok maka siswa dapat memahami dan memperoleh informasi baru mengenai kecerdasan emosional dan penerimaan teman sebaya di sekolah.

Adapun materi layanan yang dapat diberikan yaitu sebagai berikut:

Kecerdasan emosional

Topik tugas yang dapat diberikan yaitu memahami emosi dalam berbagai situasi, dan memahami emosi orang lain. Dengan materi ini, siswa nantinya mampu memahami berbagai emosi yang dialaminya serta tidak terpengaruh oleh emosi tersebut, misalnya ketika marah, siswa mengetahui penyebab emosi marah tersebut dan tidak terpengaruh oleh emosi tersebut.

Penerimaan teman sebaya

Topik tugas yang dapat diberikan yaitu humor sebagai hiburan bukan celaan, dan bersahabat itu menyenangkan. Dengan materi ini, siswa nantinya mampu belajar dan bermain dengan baik bersama teman-temannya tanpa harus ada yang merasa dikucilkan dan menjadikan humor atau candaan sebagai hiburan, bukan untuk mencela ataupun menghina teman lainnya. Dengan demikian siswa akan mendapat penerimaan yang baik dari temantemannya.

\section{Kesimpulan dan Saran}

Berdasarkan hasil analisis data yang telah dibahas tentang hubungan kecerdasan emosional dengan penerimaan teman sebaya di SMPN 4 Padang, maka dapat disimpulkan sebagai berikut: tingkat kecerdasan emosional siswa SMPN 4 Padang berada pada kategori tinggi, Artinya sebagian besar siswa SMPN 4 Padang memiliki kecerdasan emosional tinggi. Penerimaan teman sebaya siswa SMPN 4 Padang berada pada kategori baik, Artinya sebagian besar siswa SMPN 4 Padang merasa dirinya diterima dengan baik oleh teman sebayanya. Terdapat hubungan positif yang signifikan antara kecerdasan emosional dengan penerimaan teman sebaya di SMPN 4 Padang. Artinya, semakin tinggi kecerdasan emosional siswa maka semakin baik penerimaan teman sebaya. Sebaliknya, semakin rendah kecerdasan emosional siswa maka semakin tidak baik penerimaan teman sebaya.

Berdasarkan kesimpulan dan hasil penelitian, maka akan disampaikan beberapa saran kepada pihak-pihak terkait: Bagi guru BK diharapkan mampu menyusun program BK berkaitan dengan kecerdasan emosional dan penerimaan teman sebaya melalui berbagai layanan bimbingan dan konseling seperti pada layanan informasi, layanan penguasaan konten, layanan konseling perorangan dan layanan bimbingan kelompok. Bagi peneliti selanjutnya, karena penelitian ini dapat dijadikan sebagai bahan informasi awal tentang hubungan kecerdasan emosional dengan penerimaan teman sebaya. Selain itu, bagi peneliti selanjutnya diharapkan dapat memperkaya penelitian ini dengan mengambil variabel lain berkaitan dengan kecerdasan emosional dan penerimaan teman sebaya.

\section{Kepustakaan}

Astarini, D, Nirwana, H \& Ahamad, R. (2016). Hubungan antara Konsep Diri Sosial, Persepsi Siwa tentang Dukungan Sosial Orangtua, dan Teman Sebaya dengan Komunikasi Interpersonal Siswa dan Implikasinya terhadap Pelayanan Bimbingan dan Konseling. Konselor, 5(4).

Astuti, D. (2009). Hubungan antara Kecerdasan Emosional dengan Tingkat Depresi pada Remaja. Psycho Idea, Tahun 7, No. 1. ISSN 1693-1076.

Aswida W, Marjohan, Syukur Y. (2012). Efektifitas Layanan Bimbingan Kelompok dalam Mengurangi Kecemasan Berkomunikasi Pada Siswa. Jurnal Ilmiah Konseling, 1(1).

Fatimah, E. (2006). Psikologi Perkembangan (Perkembangan Peserta Didik). Bandung: CV. Pustaka Setia.

Firman \& Nurmina. (2008). Upaya Sekolah dalam Penanggulangan Agresivitas Remaja di SMA Provinsi Sumatera Barat. Glia, 56(14), 1552-1565. http://doi.org/10.1002/ajim.20908.

Fitri, Y.A, Firman, \& Karneli, Y. (2016). Efektivitas Layanan Informasi dengan Pendekatan Role Playing untuk Meningkatkan Penyesuaian Sosial Siswa Kelas VII SMPN 3 Batusangkar. Jurnal Ilmiah Konseling, http://ejournal.unp.ac.id/index.php/konselor.

Goleman. (1996). Emotional Intelligence (Terjemahan). Jakarta: Gramedia Pustaka Utama. 
Goleman. (1999). Kecerdasan Emosi untuk Mencapai Puncak Prestasi. Jakarta: Gramedia Pustaka Utama.

Herawaty, Y. (2015). Hubungan antara Penerimaan Teman Sebaya dengan Kebahagian pada Remaja. AnNafs, 9(3).

Hurlock. E. B. (1980). Psikologi Perkembangan; Suatu Pendekatan Sepanjang Rentang Kehidupan. Edisi Kelima. Terjemaham oleh Istiwidayanti dan Soedjarwo. Jakarta: Erlangga.

Octaviyana, Firman, \& Daharnis. (2017). The Contribution of Social Conflict with Peers toward Self Confidence. Jurnal Internasional Bimbingan dan Konseling, 1(1).

Paulo \& Peter. (2004). Emotional Regulation Abilities and the Quality of Sosial Interaction, Jurnal. Department of Psychology. Yale University.

Prayitno \& Amti, E. (2004). Dasar- dasar Bimbingan dan Konseling. Jakarta: Rineka Cipta.

Prayitno, E. (2006). Psikologi Perkembangan Remaja. Padang: Angkasa Raya.

Purnama, N. R. (2016). Masalah Siswa pada Masa Pubertas dan Implikasinua terhadap Layanan BK. Skripsi. Tidak diterbitkan. Padang: BK FIP UNP.

Rahmawati, U. M. (2013). Kontribusi Penerimaan Teman Sebaya terhadap Pengungkapan Diri Siswa Kelas VIII SMP Negeri 1 Masaran Tahun Pelajaran 2013/2014. Jurnal FKIP Universitas Sebelas Maret.

Rosida, E. R., \& Astuti, T. P. (2015). Perbedaan Penerimaan Teman Sebaya Ditinjau dari Tipe Kepribadian Ekstrovert dan Introvert. Jurnal Empati, 4(1), 77-81.

Sahputra D, Syahniar, \& Marjohan. (2016). Kontribusi Kepercayaan Diri dan Kecerdasan Emosi terhadap Komunikasi Interpersonal Siswa serta Implikasinya dalam Pelayanan Bimbingan dan Konseling. Konselor, 5(3).

Santrock, J. W. (2003). Adolescence Perkembangan Remaja; alih bahasa oleh Shinto B.Adelar \& Sherly Saragih. Jakarta: Erlangga.

Santrock, J. W. (2007). Remaja, Jilid 2; alih bahasa oleh Benedictine Widyasinta. Jakarta: Erlangga.

Tohirin. (2011). Bimbingan dan Konseling di Sekolah dan Madrasah (Berbasis Integrasi). Jakarta: Rajawali Pers.

Yanuarwati, A. (2014). Hubungan Penyesuaian Sosial Remaja dengan Penerimaan Teman Sebaya di SMP Negeri 1 Rajagaluh Majalengka. Skripsi Online. Yogyakarta: BKI FDK UIN Sunan Kalijaga. 